\title{
Prevalence of Ritual Images in Yoruba Nollywood Films and the Perception of Contemporary Society
}

*Olugbenga ELEGBE

\begin{abstract}
Studies have shown that a majority of Nollywood movies are a reflection of the Nigerian peopleâs traditional and cultural performances. This study posits that these themes are always explored to reinforce the existing cultural values and beliefs in the society. It is against this backdrop that this the study examined the influence of ritual images in three selected Yoruba Nollywood films; Okanran (2014), Alani Pamolekun (2015) and Ija Yemoja (2016) on the viewers and the applicability to solve real life problems. Employing the content analysis and survey technique, evidence shows that the audience are exposed to the prevalence of ritual images such as; charms, sacrifice, incantation, spell, concoction, wands, totems, shrines and other ritual performances in Yoruba films. The sampled audience observed that the projection of ritualism in Yoruba Nollywood movies is overemphasized as the reality of such practice is not so common in real life situations. Hence, there is a need for film producers to censor the overemphasis of certain cultural themes as these may somewhat be at the detriment of film audience and their perception of reality.
\end{abstract}

Keywords: Ritual images, Audience, Reception, Yoruba Nollywood movies

\section{Introduction}

Rituals are a feature of all known human societies. They include not only the worship rites and sacraments of organized religions and cults, but also rites of passage, atonement and purification rites, oaths of allegiance, dedication ceremonies, coronations and presidential inaugurations, marriages and funerals and many other

*Olugbenga ELEGBE of the Department of Communication and Language Arts,

University of Ibadan, Ibadan Email: elegbeolugbenga@gmail.com 
ritualistic events. Ritual features are the bedrock of African culture and religion. Religion is an integral part of African traditional life which constitutes the bedrock of majority of the themes and storylines of the earlier film productions (Dipio, 2007). The ritual faith and religion in African traditional worship is thus deeply embedded in almost every socio-religious rituals. It enhances their identity as a people and offers clues to understanding their cosmological framework and thought patterns. Since Africans believe that God is a higher spiritual force that is involved in their affairs as a community and individuals, they reach out to him through other gods and minor deities like Sango the god of thunder; Ogun, the god of Iron; Ala the earth goddess; Ajoku, the yam god; Osun, the river goddess and several others. However, on the individual level, there is always a personal or family god who is considered to wade off evil and bring goodluck to individuals and families. This understanding frequently gets represented in majority of Nollywood films, especially in rituals and symbolically conveys the notion of faith in God and the gods, not only in the traditional setting, but also in modern day African society. African traditional religion encompasses beliefs in a supreme God, other gods, ancestors, communal rituals, personal rituals and recognizes the existence of witchcraft, magic and sorcery, sacred specialists and other spiritual forces (Alawode and Fatonji, 2013).

The Nigerian film industry known as Nollywood according to Alawode and Fatonji (2013) is a replica of what transpires within socio-cultural, political and religious contexts in Nigeria. Uwah (2011) argues that the passage of films from stage productions to celluloid filmmaking originated with the Yoruba travelling theatres in which the major influence gave inspiration to Nollywoodôs cinematic practices. He emphasized that ñNollywood settings are familiar with Nollywood plots which depict situations that people understand and confront daily: romance, comedy, the occultô Even in the horror genre or in action films, Nigerian videos are clearly orientated toward everyday life in Africa. Traditional aspects such as magic and witchcraft are integrated into the plots. Hence, the Nigeria Nollywood films are a reflection of some of the cultural and traditional performances such as rituals and festival celebration. 
Adagbada (2014) stated that ñitual as a religious is a ceremony which involves communication with some external forces. It embodies a belief/beliefs and it is done with seriousness and solemnityò(p.15). Alawode and Fatonji (2013) described ritual as a place where people integrate short-term pragmatic goals and the longer-range mythic values of a culture, where they can replace personal alienation with an affirmation of personal identity. They submitted further ñthat every societyôs attempt to mobilize itself to solve its broader societal problems leads to an emphasis on authoritarian institutions, creation of status differentiation, justification of the concentration of power inequality, reward of individual ambition, technical knowledge and other forms of structure, which often lead to conflict, alienation and oppression. This holds that ritualism is a panacea to solving lifeôs problems. Adisa (2005) opines that rituals belong to the realm of the sacred, involving sacrifices, essentially. Sacred ritual involves sacrifices for life crises, death rites and customs and rituals of initiations. Non-sacred rituals on the other hand are the imitative types, signifying re-enactment. Under the sacred type of rituals, the positive ones are usually concerned with consecrating or renewing a religious object. In the film, Aromodomo (Generations) for instance ó́rùgàlèô the ancestral divinity is brought out from its sanctuary to the open once yearly. A goat is slaughtered and its blood poured on the ó́rùgàlèô carvings, symbolizing its being washed anew for another year, amidst drumming, dancing and feasting.

Alawode and Fatonji (2013) giving a background to the emergence of Nollywood in 1992, stated that the era of Colonial rule witnessed films produced primarily aimed at propagating political, social and economic policies of the colonial administration and Western cultural values at the expense of domestic ones. In summation, all the films produced at these period ñexhibited a common feature: in intent, content and execution; they were all based on propagandaé deeply rooted in colonialism with the affirmation and glorification of the colonizerôs culture as better and the negation or mockery of the colonized culture (Alawode and Uduakobong, 2013 p.115) But this later changed in the 70ôs when 
indigenous players began to surface when the first independent film, an adaptation of Wole Soyinkaôs ñKongiôs Harvestò, was made in 1970 (Alawode and Fatonji, 2013). However, according to Williams (2006), ñNollywood later began to focus on tenets of African nationalism and cultural identity.ò In support of this assertion, Alawode and Uduakobong (2013) further stated that culture facilitates development and also provides ample raw materials for the film maker to work with. Folklores, myths, fabrics, legends, folk music, folk dance, costume, folk architecture, ritual practices, kingship rites; and other elements and aspects of culture are ready materials that the filmmaker can explore, borrow, adapt or use verities in his work.ò

The beginning of indigenous Yoruba films productions witnessed producers like Ola Balogun, Duro Ladipo, Adebayo Faleti, Adeyemi Afolayan among many others who produced the early Yoruba movies and delved into the development of the industry in their use of the language, the marriage of cinema and tradition and the development of poetic inspiration and expression on the issue of traditional African magic and culture. Hence, themes in Yoruba home video now revolves around the potent power of the gods, their relationship with the living and their influence on human activities and the relationship between the born and the unborn (Nwogu, 2007). The themes of religious rites and rituals in Yoruba movies are performed to impress people with their duties to the community and recall to those assuming positions of chieftaincy that they should not use their power for their own interest but to serve the whole community.

There are three moments in the ritual process: leaving the realm of structure, entering into symbolic experience of community which is deeply emotional and pleasurable and the returning to the context of structure with a sense of social values. According to Alawode and Fatonji (2013) ñitual is celebratory, consolatory and decorative, rather than utilitarian in aim and often requires some element of óperformanceôfor communication to be realized. Relatively, Nigerians experience (in everyday life) communality in festivals, traditional dancing tunes and steps, 
religious worships and socio-cultural cooperationò (p.64). The argument here is that the Nigerian cultural values are not adequately portrayed in themes of Nollywood movies. This is however debatable. But the truth of this argument lies in the reasons given to justify their position. The display of witchcraft, ritual killing, immorality etc. as major prevailing themes in Nollywood movies is argued as not being representative of the true Nigerian indigenous society. The proponents of this view believe the Nigerian society is much more than the movies portray. In spite of the commendations that Nigerian Nollywood has been receiving from viewers all over the world, some of the movies, especially Yoruba movies, have been attracting criticisms as regards how fetish practices are portrayed in such movies. The prevalence of ritual themes in Yoruba movies is a subject for research. In view of this, the study examines the prevalence of ritual images in Yoruba Nollywood movies, the extent to which ritual images influence viewerôs lifestyles and their perception about life.

\section{Method}

The study adopted a content analysis and survey methods to investigate the three Yoruba Nollywood movies, Alani Pamolekun, Ija Yemoja and Okanran which were purposively selected based on their content. Content categories developed for the study include year of film, type of film, ritual contexts or locations, location design, day part, shooting set, ritualist gender and group, ritualist role or rank, ritualist age and costume, ritualist clientele, ritualist introduction/lead/link, purpose of rituals, instrument of rituals, medium of rituals, spiritual dimensions, ritual totems/objects, use/application and activation of rituals and duration of ritual scenes. Standard coding guide was also designed to ensure uniform coding of the variables. Scenes of rituals constitute the unit of analysis of the study. The data gathered were then subjected to frequency count as well as percentages. 
Synopsis of the Selected Movies

Movie 1: Okanran (2014): Producer/Scriptwriter: Idowu Adenekan

The movie is a traditional based home video that exhibits the true pictures of African social cultural prowess. The film starts with capturing of Okanran- Odunlade Adekola, who is later helped out of the custody through the deployment of an invisible sacrifice offered to Okanran in the prison. He is weak but manages to eat the concoction from the big calabash that contains all the sacrificial ingredients such as white pap, palm oil, snails and locus beans. Okanran lands in Digboluja shrine and he is later treated with local herbs. Okanran empowers his gang with terrible charms and incantations are rendered for protection to safeguard the lives of his men.

Okanran offers charm to Digbolujaôs wife and she is directed to plant it in Digbolujaôresident. Digboluja suspects his wife and he casts spell on her and Okanran, is having sex with Digbolujaôs wife and the spell cast on Digbolujaôs wife eventually weakens him but he manages to turn into a tortoise.The Erin warlord-Ina Loju Ekun picks the tortoise from the ground and he declares Okanran dead to the king and people of Erin. Ina Loju Ekun becomes the hero. He is celebrated by both the old and the young of the community. There is triumphant display from the masquerades. Erin community returns to peace.

Main Cast: Odunlade Adekola, Idowu Adenekan, Taiwo Hassan, Yinka Quadri, Ibrahim Chatta, Taofeek Digboluja, Fausat Balogun, Tunde Owokoniran and others.

Movie 2: Alani Pamolekun (2015): Producer/scriptwriter: Odunlade Adekola

Alani Pamolekun is a crime story home video filled with ritual effects from the beginning to the end. Alani is a notorious armed rubber, who commands a deadly gang. He is a powerful character, who is well protected with traditional spiritual might. He is equally grounded in occult power and employs such to threaten the community and well-meaning personalities, especially the greedy among politicians. 
There is no smoke without fire; Alaniôs traditional prowess cannot be appreciated without mentioning the significance of his spiritual godfather-Lalude, who employs all his occult intelligence to empower Alani in order to carry out ordeals. Alani is empowered with both appearing and disappearing act. He employs this act to discover and threaten his victims. Like any other traditionalist, Alani has the occult power to discover who is summoning his spirit in the spiritual realm. Alani through his spiritual godfather constantly calls for more occult power by killing innocent people for rituals; so to gain more power to see both in the physical and the unphysical world. After a lot of efforts, Alani is rendered incapacitated and he is eventually bundled into the police patrol van.

The prevalence of traditional power and other ritual processes in the film-Alani Pamolekun reveals the potency of African traditional power, which is said to be dark art. However, as it is displayed in the play, such power like any other kind of power could intoxicate the individual, who possesses it. Unfortunately, it is the same African traditional power and that of occult power that protects Alani as well as his godfather-Fadola, and his police daughter-Olabisi that is eventually employed to get rid of them.

Main Cast: Odunlade Adekola, Murphy Afolabi, Yomi FashLanso, Saidi Balogun, Fatai Odua, Dayo Amusa, Kelvin Ikeduba, Segun Ogungbe, Eniola Ajao and others.

\section{Movie 3: Ija Yemoja (2016): Producer/Scriptwriter: Ishola Durojaye}

Ija Yemoja is a myth based Yoruba movie written and produced by Ishola Durojaye. The film is a reflection of Yoruba cultural beliefs and the recent disposition of people towards such cultural understanding. Olokuta is attacked and it is displaced by warriors from the neighbouring community. The king and his subjects are forced to leave their settlement and relocate elsewhere. They take the pains of trekking many miles before consulting the Ifa oracle to help them find a suitable location to settle down. At the river bank, the Ifa priest consults the oracle through his divination device and the new settlement is found. In order to make the new place 
habitable, peaceful and prosperous for the people, the king and his first daughter are offered for sacrifice to the river goddess-Iyemoja. The late king transfers the mantle of authority to his immediate younger brother, who later becomes the new king after his brother offered himself for sacrifice. The new king promises to be obedient and maintain the values of Iyemoja.

Bolatitoôs younger brother Jaiye (Segun Ogungbe) and his friend are at the Iyemojaôs shrine. They are disturbed because properties worth millions of naira are found at the site of Iyemoja. The is a conspiracy between the queen (Faithia Balogun) and Abore- the chief priest, with Jaiye and his associates to steal all the treasure deposited at the Iyemoja Shrine. Their success is shortlived as they are able to steal from the shrine but they are unable to enjoy their loot as the river goddess kills them one after the other. The King (Odunlade Adekola) and his Olori (Faithia Balgun) observe that live fish are found in and around the palace. He calls the Ifa priest to find out the situation surrounding this matter.

The Ifa priest consults the oracle and begs the indulgence of the king to call the attention of the queen as she has a saying in the matter. However, the queen has earlier informed the king about her involvement but she threatens the king not to say anything about it as the kingố name will equally be tarnished. The queen confesses and she points at the chief priest as her accomplice in the atrocities committed against the culture of the land. The king orders the queen to leave the palace and the chief priest is asked to leave Aje Olokuta settlement. The Ifa priest thereafter proclaims that the king must leave the throne for concealment of high level secret. The community of Aje Olokuta is now left in the dilemma of uneasiness as the disobedience of the river goddess will often attract punishment in future.

Main Cast: Alani Omilani, Odunlade Adekola, Adebayo Salami, Ishola Durojaye, Faithia Balogun, Tayo Odueke, Segun Ogungbe, Dele Odule, Ganiu Nafiu and Ibrahim Chatta

\section{Findings: Characteristics of Ritual Images in the Movies}

The characteristics of ritual images in the movies were determined through the following contents categories: ritual images, ritual 
language, ritual practice, verbal content and non-verbal content. These categories were examined in the movies to see the extent to which they were present. Analysis of these categories is presented in table 1 .

Table 1 Content Categories Found in the Texts

\begin{tabular}{|l|l|l|l|}
\hline Ritual Images & Ritual Practice & \multicolumn{2}{|c|}{ Ritual Language } \\
\hline Charms & Sacrifice & Verbal & Nonverbal \\
\hline Totems & Witchcraft & Incantation & Mask \\
\hline Wands & Rite & Invocation & Totem \\
\hline Shrine & Concoction & Chants & Sacrifice \\
\hline Mask & & Ifa Eulogy & Concoction \\
\hline Apparition & & Casting Spell & Witchcraft \\
\hline & & Cursing & Rite \\
\hline & & & Charms \\
\hline & & & Wands \\
\hline & & & Apparition \\
\hline
\end{tabular}

Table 1 reveals the display of ritual images like charms, totems, wands, shrine, masks and apparitions; the ritual practices show the display of sacrifice witchcraft, rites and concoctions while the ritual language in terms of verbal communication shows the use of incantations, invocations, chants, eulogy, casting spell and cursing while the non-verbal aspects reveal the use of masks, totems, sacrifices, drinking of concoctions, display of witchcrafts, performing rites or rituals, wearing of charms, wands and seeing of apparitions.

This shows the display of more of nonverbal ritual activities in the selected movies. In other words, ritualism from this point of view is a multifaceted activity. Therefore, within the African context, ritualism refers to a wide range of traditional spiritual religious activities carried out to invoke the gods or ancestral spirits for a particular course. The nonverbal ritual contents are images that depict process of identification or 
communication with ancestral spirits, which African traditional religion employed to interact with their gods or deities. Hence, the combination of both verbal and nonverbal ritual contents was deployed to achieve this purpose.

Ritual performances in the three movies are carried out through the use objects that are peculiar to dark arts. In the movie Alani Pamolekun, nonverbal ritual contents such as totem, charms, wand, sacrifice, rite, apparition and concoction are employed to exhibit ritual performance in the text. These ritual objects and preparations are employed by Ina loju Ekun in Okanran, by Oluawo in Ija Yemoja and Fadola in Alani Pamolekun. These are essentially some of the basic handy tools or ritual effects used by traditional practitioners or shaman as a form of their ritual identification or identity to resolve problems or communicate with the gods.

Table: 2 Content of Categories of Ritual Features in the three Movies

\begin{tabular}{|l|l|l|l|l|}
\hline S/N & Ritual Indexes & $\begin{array}{l}\text { Alani } \\
\text { Pamolekun }\end{array}$ & $\begin{array}{l}\text { Ija } \\
\text { Yemoja }\end{array}$ & Okanran \\
\hline 1 & Mask & 1 & --- & 1 \\
\hline 2 & Incantation & 9 & 2 & 10 \\
\hline 3 & Charms & 6 & 4 & 12 \\
\hline 4 & Sacrifice & 4 & & 5 \\
\hline 5 & Shrine & 4 & & 11 \\
\hline 6 & Apparition & 4 & 6 & 2 \\
\hline 7 & Totem & 6 & 6 & 8 \\
\hline 8 & Spell/Curse & 3 & 2 & 2 \\
\hline 9 & Chants & 2 & 3 & 1 \\
\hline 10 & Rite & 2 & 3 & 1 \\
\hline 11 & Invocation & 2 & 2 & --- \\
\hline 12 & Concoction & 2 & 1 & 2 \\
\hline 13 & Witchcraft & ---- & 5 & 2 \\
\hline
\end{tabular}

Table 2 shows the extent to which ritual images were displayed in the three movies. The display of charms (12), incantations (10), 
Shrine (11) and Totem (8) was high in Okanran while the display of incantations (9), charms (6) and totem (6) was high in Alani Pamolekun and the display of apparitions (6), totem (6) and witchcrafts was predominant in Ija Iyemoja. This shows that the displays of these images are common across the three movies.

\section{Perception of the Viewers about Ritual Practices in the Selected Yoruba Movies}

The aims are to examine viewersôperception about ritual practices in selected Yoruba movies.

Table 3: Audience Perception of Ritual Images in Selected Movies

\begin{tabular}{|c|c|c|c|c|c|}
\hline $\mathbf{S} / \mathbf{N}$ & Questions & Agree & Disagree & $\begin{array}{l}\text { Undecid } \\
\text { ed }(\%)\end{array}$ & $\begin{array}{l}\text { Total } \\
(\%)\end{array}$ \\
\hline 1 & $\begin{array}{l}\text { Rituals displayed in } \\
\text { Yoruba movies do not } \\
\text { enhance its culture but } \\
\text { portray it in bad light }\end{array}$ & $147(96.8 \%)$ & $1(0.8 \%)$ & $2(1.5 \%$ & $\begin{array}{l}130 \\
(100 \%)\end{array}$ \\
\hline 2 & $\begin{array}{l}\text { Audience do not have } \\
\text { adequate knowledge } \\
\text { about the reality of } \\
\text { ritual practices in the } \\
\text { movies }\end{array}$ & $122(93.8 \%)$ & $6(4.6 \%)$ & $2(1.5 \%)$ & $\begin{array}{l}130 \\
(100 \%)\end{array}$ \\
\hline 3 & $\begin{array}{l}\text { Ritual Practice in the } \\
\text { movies is evil and } \\
\text { does not depict the } \\
\text { state of things in the } \\
\text { society }\end{array}$ & $119(91.3 \%)$ & $9(6.9 \%)$ & $2(1.5 \%)$ & $\begin{array}{l}130 \\
(100 \%)\end{array}$ \\
\hline 4 & $\begin{array}{l}\text { Excessive use of ritual } \\
\text { in movies can } \\
\text { negatively pollute } \\
\text { audience mind. }\end{array}$ & $99(79.2 \%)$ & $\begin{array}{l}23(17.7 \\
\%)\end{array}$ & $2(1.5 \%)$ & $\begin{array}{l}130 \\
(100 \%)\end{array}$ \\
\hline 5 & $\begin{array}{l}\text { Application of rituals } \\
\text { to resolve problems in } \\
\text { Yoruba movies does } \\
\text { not encourage good } \\
\text { judicial process }\end{array}$ & $84(64.6 \%)$ & $\begin{array}{l}38(29.2 \\
\%)\end{array}$ & $6(4.6 \%)$ & $\begin{array}{l}130 \\
(100 \%)\end{array}$ \\
\hline 6 & $\begin{array}{l}\text { Rituals in Yoruba } \\
\text { movies have negative } \\
\text { influences on the } \\
\text { society. }\end{array}$ & $122(93.8 \%)$ & $6(4.6 \%)$ & $2(1.5 \%)$ & $\begin{array}{l}130 \\
(100 \%)\end{array}$ \\
\hline
\end{tabular}


Table 3 shows that $96.8 \%$ of the audience perceive that rituals displayed in Yoruba movies do not enhance its culture but portrays it in a bad light, $93.8 \%$ perceived that the audience do not have adequate knowledge about the reality of ritual practices in the movies, $91.3 \%$ perceived that ritual practice in Yoruba movies is evil and does not depict the state of things in the society, $79.2 \%$ believed that excessive use of ritual in Yoruba movies can negatively pollute audience mind, $64.6 \%$ perceived that application of rituals to resolve problems in Yoruba movies does not encourage good judicial process and $93.8 \%$ believed that rituals in Yoruba movies have negative influences on the society.

\section{How Ritual Images in Yoruba Nollywood Movies Influence Audience Perception of Life}

This question is an attempt to discover whether the ritual images as seen in the movies have any influence on the viewersôperception ways of life.

Table 4: Ritual Images and Viewers' Perception Life

\begin{tabular}{|l|l|l|}
\hline Responses & Number & Percentage \\
\hline Yes & 91 & $70 \%$ \\
\hline No & 32 & $24.6 \%$ \\
\hline Indifferent & 7 & $5.4 \%$ \\
\hline Total & 130 & $100 \%$ \\
\hline
\end{tabular}

Based on the data presentation above, it is observed that $70 \%$ of viewers are of the opinion that the ritual images in Yoruba movies influence their perception of life.

Table 5: Ritual images and Influence on viewers Lifestyle

\begin{tabular}{|l|l|l|}
\hline Responses & Number & Percentage \\
\hline Positively & 47 & $36.2 \%$ \\
\hline Negatively & 83 & $63.8 \%$ \\
\hline Others & - & - \\
\hline Total & $\mathbf{1 3 0}$ & $\mathbf{1 0 0 \%}$ \\
\hline
\end{tabular}


Table 5 shows that $63.9 \%$ respondents are negatively influenced by the images of rituals they watched in the movies. With this negative index identified above, it suggests that the use of ritual images has negative impact on the lifestyle of the respondents.

Table 6: Viewers Employ Ritual Items/Language as Used in the Films

\begin{tabular}{|l|l|l|}
\hline Respondents & Number & Percentage \\
\hline Yes & 14 & $10.8 \%$ \\
\hline No & 113 & $86.9 \%$ \\
\hline Indifferent & 3 & $2.3 \%$ \\
\hline Total & $\mathbf{1 3 0}$ & $\mathbf{1 0 0 \%}$ \\
\hline
\end{tabular}

Table 6 shows that $86.9 \%$ respondents are of the opinion that they do not make use of ritual items and language as employed in the movies. This implies that although, the concepts in the movies are unique to cultural practices but viewers do adopt the choice of words in their day to day activities. This shows that most images shown in these movies were not practised by viewers.

\section{Discussion}

The movies show the characteristics of ritual images displayed in the selected movies like charms, totems, wands, shrine, masks and apparitions; the ritual practices like the display of sacrifice, witchcraft, rites and concoctions while the ritual language in terms of verbal communication like the use of incantations, invocations, chants, eulogy, casting spell and cursing while the non-verbal aspects reveal the use of masks, totems, sacrifices, drinking of concoctions, display of witchcrafts, performing rites or rituals, wearing of charms, wands and seeing of apparitions. This prevalence of ritualism supports the submission of Alawode and Fatonji (2013) that ñitualism is an important aspect of African traditional religion and it is one of the dominant themes portrayed in Nigerian movieò (p.70), which was also predominant in Yoruba movies. The cultural totems used, the spiritual dimensions and medium of rituals are embedded in African traditional religion. 
The study also shows that the audience perception about the rituals displayed in Yoruba movies does not enhance its culture but depicts the falsehood about the state of things in the society which can negatively pollute audience mind and their manner of judging things. This submission supports the views of Okon (2015) in which he emphasized that the display of witchcraft, ritual killing, crass immorality etc. as major prevailing themes in Nollywood movies is argued as not being representative of the true Nigerian indigenous society. He states further that the Nigerian society is much more than these movies portrayed. However, Ekeanyanwu (2010) in a related study argues that ñthe early Nollywood movies presented a stereotyped and fixated view of the Nigerian culture. They gave the impression that, áhe Nigerian society is blood-sucking, witch-craft infested and secret-cult pervasive.ò From another perspective, Alawode and Uduakobong (2013) argued that ñNigerian cultures are revealed in the films packaged in the home videos. The story line/themes, lifestyles, foods, norms and values and even manner of dressing reveal the ways of life of the people.ò

This is also supported by Tasie (2013) who says that ña very dominant theme in most Nigerian video films is the close association of occult rituals with African indigenous religion. This is understandable; for a film reflects its societyô ideals and values.ò But Ezegwu, Okeckukwu, and Etukudo (2016) felt that when themes are overdone and made the centre of movies it can become a problem because the more people see it, the more they will think that our country is all about voodoo practice. Nevertheless, the study shows that those displays of rituals influence viewerôs life style and perception of life but most images shown in these movies were not practised by viewers. Akpabio (2007) traced emphasis on negative themes by Nigerian home videos to marketers who do this to satisfy their profit maximization. Tasie (2013) summed it up thus that ñn the light of this negative portrayal of the indigenous religioné African indigenous religion is still seen as second-rate.ò This shows that the prevalence of rituals images in Yoruba movies without good 
storyline and lesson learnt for the teeming population of the movies audience will continue to show wrong perception about black African arts and culture as being full of witchcraft, sorcery and negative spiritual connotations.

\section{Conclusion/ Recommendations}

The display of rituals images in Yoruba movies will continue to show the Yoruba society as crude and underdeveloped even though the marketer will smile to the bank everyday with huge profit. Hence, film scriptwriters and producers are enjoined to recreate artistically the authentic ritual and cultural practices that are embedded in Yoruba tradition, to reflect modern realities and platform to teach good values to the viewers. The viewers should not allow the scenes in the movies to influence their ideology as the ritual performances in the movies were not often times the real antidote to resolve such difficult situation as being played out in the movies. Also, the audience should understand that most of the ritual performances in the movies were mere make believe as none of such expression of ritual practices are panacea to peopleôs challenges in contemporary society.

\section{References}

Adagbada, O. (2014). Sociological analysis of money rituals as a recurrent theme in Yoruba films. New Media and Mass Communication, 32, 13-20.

Adisa, O.A. (2005). ñRituals and governance in Yoruba societyò. M.A. Dissertation, Department of Linguistics and African Languages, University of Ibadan, Nigeria.

Akpabio, E. (2007). Attitude of audience members to Nollywood films. Nordic

Journal of African Studies, 16 (1), 90-100.

Alawode, S.O. \& Fatonji, S.S. (2013). Ritualism in Nigerian home videos. Paper

presented at the 1st Annual International Interdisciplinary Conference (AIIC), Azores, Portugal.

Alawode, S.O. \& Uduakobong, S. (2013). Home video as Nigerian image maker. European Scientific Journal, 9 (11), 110-128 
Dipio, D. (2007). Religion in Nigerian home video films. Westminster Papers

in Communication and Culture, 4(1), 65-82.

Ekeanyanwu, N.T. (2010). Nollywood and Nigeriaôs indigenous cultural values: The Developmental imperatives. In E. Soola, H. Batta and C. Nwabueze (Eds.), Communication and Africa's development crisis: Essays in honour of Professor Des Wilson (pp.131-143). Berlin: VDM Verlag.

Ezegwu, D.T., Okeckukwu, N.C \& Etukudo, O.R. (2016). The effect of portrayal of witchcraft/voodoo in Nollywood on Nigeriâ̂ national development. Oko Journal of Communication and Information Science, 2 (1), 1-38.

Haynes, J. \& Okome, O. 2000. Evolving popular media: Nigerian video films. In Haynes, J. Nigerian video films. Athens: Ohio University Center For International Studies. p. 51 ï 88.

Nweke, F. (2006). Ministerial oath to reinvent Nollywood. Retrieved 12 February

2017, from http//.www.ngrguardian.com.

Nwogu, L.I. (2007). Cultural promotion and image portrayal in the Nigerian movies. M.A. Dissertation Department of Theatre and Performing Arts, Ahmadu Bello University Zaria, Nigeria

Okon, G.B. (2015). Viewersôreactions to excessive ritual themes in Nigerian home videos: A Port Harcourt city survey. International Journal of Communication and Media Studies, 5 (2), 1-10.

Tasie, G. (2013). African traditional religion in Nigerian video films: A rethink. American International Journal of Social Science, 2 (1), 23-29.

Uwah, I. E. (2009). From rituals to films: A case study of the visual rhetoric of Igbo

culture in Nollywood films. PhD Thesis, Dublin City University, Ireland.

Uwah, I. (2011). The Representation of African Traditional Religion and Culture in Nigeria popular Films. Journal of Politics and Religion, 5 (1), 81-102. 


\section{Videography}

Adenekan, I . (Producer/Scriptwriter). (2014). Okanran [Motion Picture]. Nigeria. Idowu Adenekan Film Production

Durojaye, I. (Producer/Scriptwriter). (2016). Ija Iyemoja [Motion Picture]. Nigeria. GAS Motion Pictures

Kunle, A.A. (Producer/Scriptwriter). (2009). Aromodomo [Motion Picture]. Nigeria. Small World Production

Odunlade, A. (Producer/Scriptwriter). (2015). Alani Pamolekun [Motion Picture]. Nigeria. Odunlade Adekola Film

Production 